\title{
HYPERCALCAEMIA IN ADOLESCENT TETRAPLEGIC PATIENTS: CASE REPORT AND REVIEW
}

\author{
By Franz U. Steinberg, M.D., Stanley J. Birge, M.D. and Nancy E. Cooke, M.D. \\ Department of Rehabilitation Medicine and the Department of Medicine, \\ Division of Metabolism, The fewish Hospital of St Louis and Washington University, \\ School of Medicine, St Louis, Missouri, U.S.A.
}

Abstract. The paper presents the case history of a I5-year-old boy with traumatic tetraplegia who developed hypercalcaemia within 6 weeks of injury. The condition was initially controlled by the infusion of intravenous fluids in large amounts and by the administration of calcitonin. After 3 weeks, calcitonin became ineffective. Eventually the hypercalcaemia responded to cortisone administered in low dosage. The endocrinologic implications of this observation are discussed.

Key words: Tetraplegia; Spinal cord injury; Hypercalcaemia; Adrenocortical insufficiency.

HYPERCALCURIA and osteoporosis are frequent complications of spinal cord injury and other disorders that lead to immobilisation. In spite of the profound changes in calcium metabolism engendered by these conditions hypercalcaemia is extremely rare. The serum calcium level is well protected by homeostatic processes which prevent the occurrence of this serious and at times life-threatening complication. Almost all cases so far reported have occurred in adolescent males who became immobilised during a period of rapid bone growth. The only exceptions are two patients with Paget's disease, both over the age of 50, who had sustained lower extremity fractures (Reifenstein \& Albright, 1944). Therefore, an accelerated turnover of bone, whether due to rapid growth or due to bone disease, is a necessary predisposing factor to the development of immobilisation hypercalcaemia.

\section{Case Report}

M. K. is a I5-year-old boy who sustained a fracture-dislocation of the fifth and sixth cervical vertebrae on II July 1966 in a diving accident. He became tetraplegic with sensory and motor levels at $\mathrm{C}_{5}-\mathrm{C} 6$. He was admitted to the neurosurgery service of the St Louis University Hospital. Gardner-Wells tongs with $20 \mathrm{lb}$ of traction were applied and the dislocation was reduced as demonstrated by radiologic examination. The neurologic deficit, however, was not affected. He was started on a programme of intermittent catheterisation. On 27 August, after the removal of the tongs, he was transferred to the Jewish Hospital Department of Rehabilitation Medicine. On admission he presented the picture of a weak, pale, poorly nourished boy, complaining of lethargy, headache and nausea. He was tetraplegic at C5-C6 level. No spasticity was noted. The alkaline phosphatase was Ioo units (normal). The serum calcium was elevated to $14.9 \mathrm{mg}$ per IOO ml. Serum phosphorus was $4.6 \mathrm{mg}$ per $100 \mathrm{ml}$. Other laboratory data are presented in Table I.

As soon as the diagnosis of hypercalcaemia had been established and confirmed, intravenous saline and glucose were given, six litres on the Ist day and varying from 2 to 4 litres daily thereafter, supplementary to the oral fluid intake.

Potassium was added to the intravenous fluids. In spite of this precaution the serum potassium dropped to $2.4 \mathrm{mEq}$ on the 8 th hospital day. It recovered within a day and 
TABLE I

Initial laboratory data

\begin{tabular}{lcc}
\hline & Admission & After hydration \\
\hline Haemoglobin & $12 \cdot 0$ & I0.2 \\
Haematocrit & $37 \cdot 9$ & $29 \cdot 7$ \\
White blood count & 9500 & I0 200 \\
Total protein & $6 \cdot 5$ & $4 \cdot 9$ \\
Albumin & $4 \cdot \mathrm{I}$ & $2 \cdot 8$ \\
Blood urea nitrogen & 31 & 10 \\
Calcium & $\mathrm{I} 4 \cdot 9$ & $14 \cdot 4$ \\
Phosphorus & $4 \cdot 6$ & 3.6 \\
Alkaline phosphatase & I00 & 82 \\
\hline
\end{tabular}

Electrolytes: Potassium $3.0 \mathrm{mEq}$, normal otherwise.

Total hydroxyproline I $46 \mathrm{mg} / 24$ hours (normal 25-77).

thereafter it remained close to normal throughout most of the hospital stay. The serum calcium began to diminish rapidly. On the 25th hospital day when it had fallen to 10.0 mg per cent the intravenous fluids were discontinued (Fig. I). On the 2 Ist day calcitonin was added to the treatment in a dosage of 100 units twice a day. After Io days the dosage was doubled to 200 units twice a day. The initial response was gratifying. The serum calcium fell and remained close to normal limits for 3 weeks. After that period of time it again rose and it remained elevated in spite of continuing calcitonin administration (Fig. I). Oral phosphate, in the form of 3 to $5 \mathrm{ml}$ of Fleet's Phosphosoda, was

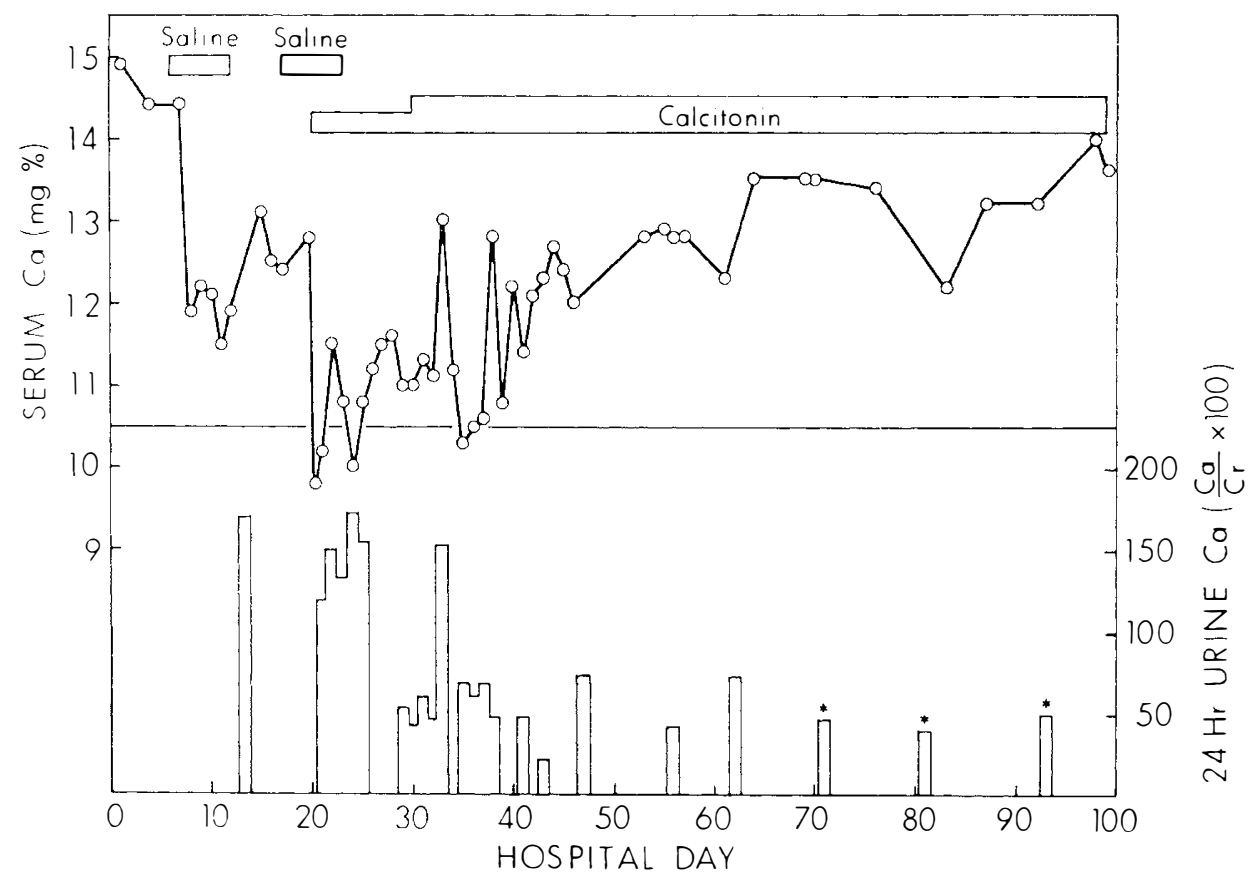

FIG. I 
given simultaneously with the calcitonin from the 79th to the 128 th day. This proved ineffective, especially since the patient frequently refused to take this medication which made him nauseated.

After the calcitonin had been discontinued the anabolic steroid stanozolol was administered in a daily dosage of $4 \mathrm{mg}$. It had no discernible effect on the serum calcium which remained elevated, varying between II and I4 mg per cent. The patient's general condition improved nevertheless. He ate with a better appetite, he was able to be up in the wheelchair for several hours a day and to participate in rehabilitation activities. In order to achieve some weight-bearing on his lower extremities he was placed on a tilt table for brief periods each day. These attempts were frustrated by frequent bouts of orthostatic hypotension. The mineral corticosteroid fludrocortisone $0 \cdot 1 \mathrm{mg}$ was given daily with only partial relief.

In a further effort to reduce the serum calcium sodium fluoride in a dosage of 20 mg three times a day was given from the I53rd hospital day on and continued for 100 days. This measure also proved to be ineffective. An investigation of parathyroid function gave no evidence of hyperparathyroidism (Table II). Most surprising was the discovery of a low plasma cortisol level of $3.4 \mathrm{mcg} / \mathrm{I} 00 \mathrm{ml}$ (normal 8-24 mcg). Since there is evidence that the synthesis of prostaglandins is increased in adrenocortical insufficiency and since these compounds are known to enhance bone resorption indomethacin, $25 \mathrm{mg}$ three times a day, was given for Io days in order to suppress prostaglandin synthesis. During this period the serum calcium level fell from 13.5 to $12.3 \mathrm{mg}$ per cent (Fig. 2).

An ACTH (cosyntropin) stimulation test indicated the presence of adrenocortical insufficiency. This was further supported by the elevation of the blood ACTH level (Table III). In response to these findings treatment with cortisone acetate $37.5 \mathrm{mg}$ per day was initiated and maintained for 2 weeks. The serum calcium began to decline promptly and fell as low as II.I mg per cent. After cortisone was discontinued the serum calcium again rose to $13.4 \mathrm{mg}$ per cent. After 18 days cortisone administration was resumed, and the serum calcium again fell to a low of $10.6 \mathrm{mg}$ per cent (Fig. 2).

Serum phosphorus levels remained within normal limits throughout his stay in the hospital. Creatinine clearance determinations were done several times and indicated

TABLE II

Parathyroid tests

\begin{tabular}{lcc}
\hline & \multicolumn{1}{c}{ I9th day } & 28th day \\
\hline Parathyroid hormone & $3.0 \mu \mathrm{ml}$ & $3.0 \mu / \mathrm{ml}$ \\
Total calcium & I $2 \mathrm{mg}$ per cent & II $\cdot 2 \mathrm{mg}$ per cent \\
Free calcium & $6.5 \mathrm{mg}$ per cent & $5.63 \mathrm{mg}$ per cent \\
Free/total calcium & 54.2 & 50.3 \\
Phosphorus & $3.6 \mathrm{mg}$ per cent & $3.8 \mathrm{mg}$ per cent \\
\hline
\end{tabular}

TABLE III

Adrenocortical function test

\begin{tabular}{lc}
\hline Plasma cortisol & $3.4 \mathrm{mcg} / \mathrm{IOO} \mathrm{ml}$ (normal 8-24) \\
ACTH stim. test (250 mcg i.m.) & $6.0 \mathrm{mcg}$ per cent \\
Plasma cortisol: $\quad$ o time & I $\cdot 0 \mathrm{mcg}$ per cent \\
2 hours & I $50 \mathrm{pg} / \mathrm{ml}$ (normal less than IOO) \\
\hline
\end{tabular}




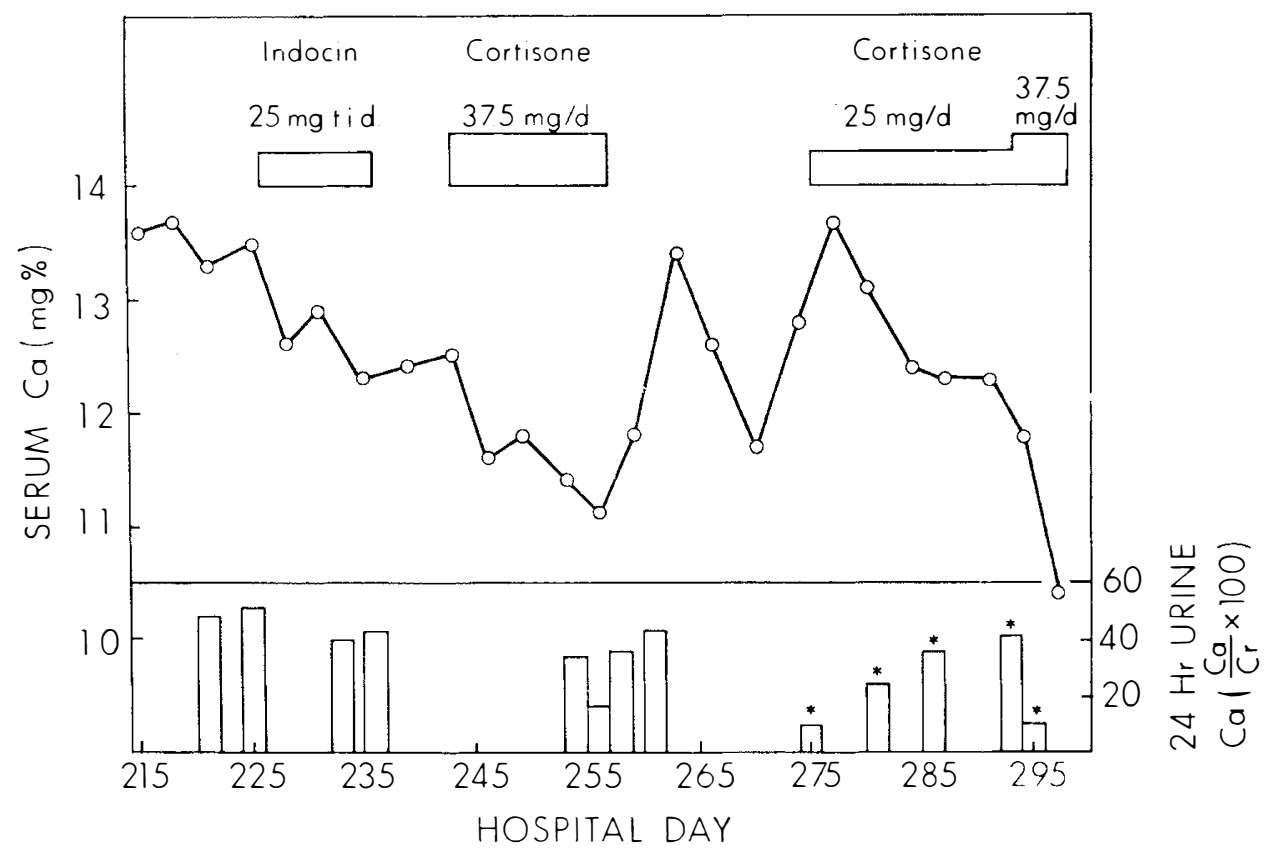

FIG. 2

reduced renal function. Serum creatinine and blood urea nitrogen remained normal. The serum electrolytes were normal. However, potassium supplements had to be given at various times to prevent a significant lowering of the serum potassium.

Egg-shell type bladder calculi were crushed and removed by cystoscopy on two occasions, on the I Ioth and 297th hospital day. Intravenous pyelograms, at two occasions, showed a normal excretion of dye and a normal kidney structure. There were no stones in the renal pelves and no calcifications in the renal parenchyma.

The patient was discharged from the hospital on the 30Ist hospital day. He will be maintained on cortisone acetate $37.5 \mathrm{mg}$ a day for 5 days each week. His general condition was satisfactory at the time of discharge.

\section{Discussion}

Immobilisation hypercalcaemia was first reported by Albright et al. (I94I). Their patient, a I4-year-old boy, developed osteoporosis, hypercalcaemia, hypercalcuria and renal failure during immobilisation for a fractured femur. He underwent two neck explorations in a futile search for parathyroid tumours. Since then additional cases have been reported sporadically. The literature has been thoroughly reviewed by Lawrence et al. (1973), and by Wolf et al. (1976). In his review, Wolf et al. had found only 3 I reported cases. Additional case reports have since appeared (Claus-Walker et al., I975; Henke et al., I975; Levine et al., I975; Maynard \& Imai, I977).

In almost all instances immobilisation hypercalcaemia has occurred in male adolescents who became immobilised suddenly following a life of intense physical activity. In such patients, as well as patients with Paget's disease and hyperthyroidism, both bone formation and resorption are elevated but balanced. Immobilisation diminishes bone formation while the rate of resorption is increased.

I6/I-E 
Hypercalcaemia occurs if sufficient calcium is released from bone into the blood at a rate greater than the capacity of the kidney to excrete the increased filtered load.

The hypercalcaemia may be asymptomatic but often it is associated with nausea, vomiting, constipation, abdominal cramps, weakness, lethargy, emotional instability and headaches. Encephalopathy, coma and death may ensue. The onset may occur early after immobilisation or there may be a delay of I to 3 months. Impairment of renal function has been reported by most observers and has been extensively studied by Hyman (1972). His patient, a I5-year-old boy, was found to have a decreased glomerular filtration rate, creatinine clearance and urine concentrating ability. The urinary excretion of calcium was elevated, the tubular reabsorption of phosphorus was decreased. A metabolic alkalosis developed. After 9 months all renal function tests had returned to normal following mobilisation of the patient.

The elevated serum calcium obviously suggests the possibility of hyperparathyroidism. However, in all reported cases with one exception (Henke et al., 1975) parathyroid hormone blood levels have been normal. This has also been true for our patient. Furthermore, the favourable response to glucocorticoids militates against hyperparathyroidism.

The condition is self-limited and disappears when the patient is mobilised. Unfortunately, this is often not possible in patients with spinal cord injury. The initial treatment consists of the administration of large amounts of sodium containing intravenous fluids in order to promote calcium diuresis. Furosemide may be added to this regime. The serum potassium level must be monitored, and supplementary potassium should be given as needed. Oral phosphates increase bone formation and may also be of benefit. However, as was true for our patient, they are often poorly tolerated and are frequently refused.

Calcitonin decreases bone resorption, and for this reason it may be expected to benefit in the therapy of hypercalcaemia. However, in various animal studies calcitonin failed to prevent the development of disuse osteoporosis (Chiroff \& Jowsey, I970; Braddom et al., I973). Hantman et al. (1973) studying the calcium metabolism of healthy volunteers on bedrest found that the administration of calcitonin alone without mineral supplements actually causes an increase of urinary calcium excretion, possibly due to an inhibition of tubular calcium reabsorption. Both Hantman and other investigators have suggested that the prolonged administration of calcitonin may stimulate excessive parathyroid action which cancels out the bone-sparing effect of calcitonin. In any case, in our patient calcitonin lowered the serum calcium level only during the first 3 weeks and was ineffective thereafter. Urinary calcium excretion, presented in Figure $I$ in per cent of 24-hour creatinine excretion (calcium/creatinine $\times$ I00) fell during the first weeks of calcitonin administration and then rose again.

Anabolic steroids may be expected to decrease hypercalcuria and hypercalcaemia by increasing bone formation. The hormone stanozolol which we gave to our patient was ineffective, at least in the dosage in which it was employed.

Glucocorticoids have been effective in reducing serum calcium levels in the hands of all observers who have used them. The mechanism of action is not fully understood. Even though ordinarily adrenal corticosteroids cause osteoporosis when given in large doses and for prolonged periods of time they appear to reduce the excessive bone resorption encountered during immobilisation. Furthermore, their action may be partly due to a decrease of renal tubular reabsorption of calcium and to an expansion of the extracellular fluid compartment. Most 
observers have employed corticosteroids in large doses. The potential side effects of lowering the resistance to infection and enhancing the tendency to tissue breakdown are hazardous in young, chronically ill tetraplegic patients and kept us from using this form of treatment.

The low plasma cortisol level suggested that we were dealing with an adrenal cortical insufficiency, and this impression was further supported by the results of the ACTH stimulation test. As a result we elected to use cortisone in a small dosage, as a replacement for insufficient endogenous cortisol production. The immediate and significant drop of the serum calcium in response to $37.5 \mathrm{mg}$ of cortisone a day supported this assumption. When cortisone was discontinued for I 8 days, the serum calcium rose to hypercalcaemic levels. It again fell promptly when cortisone administration was resumed.

A review of the literature uncovered only one reference in support of our assumption that adrenocortical impairment may be at least a contributing factor to the development of immobilisation hypercalcaemia. Claus-Walker et al. (I975) found a decrease of 24-hour I7-ketosteroid excretion in two patients with immobilisation hypercalcaemia in whom these determinations were made.

Hypercalcaemia has been observed in Addison's disease. Pedersen reported high serum calcium levels in two patients with this disorder. The hypercalcaemia responded promptly to replacement doses of cortisone (Pedersen, 1967). Siegler (I970) has reported one such case and Leeksma et al. (1957) also found high serum calcium levels in patients with Addison's disease. The evidence for a causal relationship between adrenocortical insufficiency and immobilisation hypercalcaemia is tenuous so far. We hope that future observers will investigate the adrenocortical function in immobilised patients who present with elevated serum calcium levels.

The relationship of corticosteroids to prostaglandins is of interest. Prostaglandins are known to enhance bone resorption and therefore they may contribute to the development of hypercalcaemia during immobilisation. That immobilised bone is particularly sensitive to hormonal influences has been demonstrated by the now classical studies of Burkhart and Jowsey (1967). It is plausible, therefore, that only moderately elevated prostaglandin blood levels may have an exaggerated osteolytic effect on bone of immobilised body parts. Two recent studies have shown that corticosteroids suppress the synthesis of prostaglandins and prostaglandin precursors (Kantrowitz et al., I975; Tashjian et al., I975). It is conceivable, therefore, that a decrease of endogenous cortisol formation may cause an increase of prostaglandin production, and that this in turn may contribute to an increase of bone resorption. This too may be a fruitful field for future research.

Immobilisation hypercalcaemia may not be as rare as the sparse reports in the literature suggest. Deitrick, Whedon and Shorr (1948) found elevated serum calcium levels in their healthy volunteers after they had been immobilised for 5 weeks or longer. Heath et al. (1972) found abnormal elevations of serum ionised calcium in nine out of ten patients who were immobilised for the treatment of fractures. Only three patients had an elevated total serum calcium. Hypercalcaemia may be asymptomatic. Symptoms, when they occur, are rather nonspecific and may easily be ascribed to depression or the effects of serious injury and prolonged bedrest. It appears advisable to periodically determine serum calcium levels in patients in the early phase of spinal cord injury. If this were done, hypercalcaemia might be discovered more frequently.

Our patient developed hypercalcaemia while on a programme of intermittent catheterisation which had made it necessary to moderately restrict his fluid intake. 
Maynard and Imai (1977) also reported that two out of their four spinal cord injured hypercalcaemic patients were on a regime of fluid restriction while on a programme of intermittent catheterisation. Therefore, in adolescent tetraplegic or paraplegic patients fluid restriction may be unwise. If a programme of intermittent catheterisation is initiated serum calcium levels should be obtained in frequent intervals.

\section{SUMMARY}

Hypercalcaemia is a rare complication of immobilisation. It almost always occurs in adolescent males who have become immobilised suddenly following a life of intense physical activity. This paper presents the case report of a I 5-yearold boy who developed hypercalcaemia 6 weeks after he had become tetraplegic in a diving accident. The treatment proved to be difficult. Calcitonin was effective only during the first 3 weeks of administration. Endocrinologic studies, however, indicated an adrenocortical insufficiency. As a result cortisone was administered in a small dosage as a replacement for the insufficient endogenous cortisol production. The hypercalcaemia responded favourably. The serum calcium level fell promptly and remained within the normal range. This observation suggests that adrenocortical insufficiency may be an important factor in the development of immobilisation hypercalcaemia. It is suggested that future observers investigate the adrenocortical function of immobilised patients who present with elevated serum calcium levels.

\section{RÉSUMÉ}

L'hypercalcémie est une complication rare causée par l'immobilisation. Elle se produit presque toujours chez les adolescents du sexe masculin qui se trouvent immobilisés soudainement après une vie d'une très grande activité physique. Ce papier présente le cas d'un jeune garçon de 15 ans qui developpa une hypercalcémie six semaines après être devenu quadriplégique à la suite d'un accident survenu en plongeant. Le traitement se révéla difficile. La calcitonine administrée ne fût efficace que pendant les trois premières semaines. Les études sur les glandes endocrines indiquèrent cependant une insuffisance corticosurrénale. Par la suite, de la cortisone fut donnée par petites doses pour remplacer la production endogène insuffisante d'hydrocortisone. L'hypercalcémie réagit favorablement. Le niveau de sérum de calcium tomba rapidement et demeura dans les limites normales. Cette observation donne à penser que l'insuffisance cortico-surrénale peut être un facteur important dans le développement de l'hypercalcémie résultant d'un état immobile. Nous suggérons qu'à l'avenir les observateurs fassent des recherches sur la fonction corticosurrénale chez les patients immobilisés présentant des niveaux élevés de sérum de calcium.

\section{ZUSAMMENFASSUNG}

Hypercalcaemie ist eine seltene Komplikation der Immobilisation. Sie befaellt meistens Jugendliche maennlichen Geschlechtes, die koerperlich sehr aktiv waren, bevor sie ploetzlich durch Krankheit oder Unfall immobilisiert wurden.-Der vorliegende Fall betrifft einen 15 jaehrigen, der durch einen Tauchunfall quadriplegisch wurde, und in dem nach sechs Wochen eine Hypercalcaemie auftrat. Die Behandlung war ausserordentlich schwierig. Calcitonin wirkte nur waehrend der ersten drei Wochen. Spaeter vorgenommene endokrinologische Untersuchungen ergaben das Vorliegen einer Nebennierenrinden Insuffizienz. Die Hypercalcaemie wurde schliesslich erfolgreich mit Cortison in kleinen Dosen behandelt, das als Ersatz fuer die ungenuegende endogene Cortisol Produktion verabreicht wurde. Diese Beobachtung erlaubt den Schluss, dass eine adrenocorticale Insuffizienz ein wichtiger Faktor in der Entstehung der Immobilisations Hypercalcaemie sein koennte. Es wird vorgeschlagen, dass in kuenftigen Faellen von Immobilisations Hypercalcaemie die Nebennierenrinden Funktion erforscht wird. 


\section{REFERENCES}

Albright, F., Burnett, C. H., Cope, O. \& Parson, W. (I94I). Acute atrophy of bone (osteoporosis) simulating hyperparathyroidism. F. Clin. Endocrin. I, 7 II.

BRADDOM, R. L., ERICKSON, R. \& JOHNSON, E. W. (I973). Ineffectiveness of calcitonin on osteoporosis in paraplegic rats, Arch. Phys. Med. Rehab. 54, I 70.

Burkhart, J. M. \& Jowsey, J. (1967). Parathyroid and thyroid hormones in the development of disuse osteoporosis. Endocrin. 81, 1053.

CHIROFF, R. T. \& JowSEY, J. (1970). The effect of calcitonin on immobilization osteopenia. F. Bone foint Surg. 52A, I 138 .

Claus-Walker, J., Carter, R. E., Campos, R. J. \& Spencer, W. A. (1975). Hypercalcemia in early traumatic quadriplegia. F. Chron. Dis. 28, $8 \mathrm{I}$.

Deitrick, J. E., Whedon, G. D. \& SHORR, E. (1948). Effects of immobilization upon various metabolic and physiologic functions in normal men. Amer. F. Med. 1, 3 .

Hantman, D. A., Vogel, J. M., Donaldson, C. L., Friedman, R., Goldsmith, R. S. \& Hulley, S. B. (1973). Attempts to prevent disuse osteoporosis by treatment with calcitonin, longitudinal compression and supplementary calcium and phosphate. $\mathcal{F}$. Clin. Endocrinol. Metab. 36, 845.

Heath, H. III, Earll, J. M., Schaaf, M., Piechocki, J. T. \& Ting-Kai Li. (I972). Serum ionized calcium during bedrest in fracture patients and normal men. Metabolism, 2I, 633 .

Henke, J. A., THOMPson, N. W. \& KaUfeR, H. (I975). Immobilization hypercalcemic crisis. Arch. Surg. I10, 32 I.

Hyman, L. R., Boner, G., THOMAS, J. C. \& SEgAR, W. E. (I972). Immobilization hypercalcemia. Amer. F. Dis. Child. 124, 723.

Kantrowitz, F., Robinson, D. R. \& MCGuire, M. B. (1975). Corticosteroids inhibit prostaglandin production by rheumatoid synovia. Nature, 258, 737.

LAWRence, G. D., Loeffler, R. G., MARTin, L. G. \& ConNer, T. B. (I973). Immobilization hypercalcaemia. F. Bone foint Surg. 55A, 87.

Leeksma, C. H. W., DE GraefF, J. \& DE CoCK, H. (1957). Hypercalcaemia in adrenal insufficiency. Acta Med. Scand. 156, 455.

Levine, C., Greer, R. B. III \& GoRDON, S. L. (1975). Hypercalcemia complicating fracture immobilization. f. Trauma, $\mathbf{1 5}, 70$.

MAYNARD, F. M. \& IMAI, K. (I977). Immobilization hypercalcemia in spinal cord injury. Arch. Phys. Med. Rehab. 58, I6.

Pedersen, K. O. (1967). Hypercalcaemia in Addison's disease. Acta Med. Scand. 181, $69 \mathrm{I}$.

Reifenstein, E. C., JR. \& Albright, F. (I944). Paget's disease: its pathologic physiology and the importance of this in the complications arising from fracture and immobilization. New England F. Med. 231, 343.

SIEGLER, D. I. M. (I970). Idiopathic Addison's disease presenting with hypercalcaemia. Brit. Med. F. 2, 522.

Tashjian, A. JR., Voelkel, E. F., McDonough, J. \& Levine, L. (1975). Hydrocortisone inhibits prostaglandin production by mouse fibrosarcoma cells. Nature, 258, 739 .

Wolf, A. W., Chuinard, R. G., Riggins, R. S., Walter, R. M. \& DepNeR, T. (I976). Immobilization hypercalcemia. Clin. Orthop. 118, I24. 